\title{
BACK IN BUSINESS: INDUSTRIAL POLICY FOR EMERGING ECONOMIES IN THE NEW GLOBALIZATION
}

Erik Berglof and Vince Cable

NO. 537

February 2018
ADB ECONOMICS WORKING PAPER SERIES 


\section{Back in Business: Industrial Policy for Emerging Economies in the New Globalization}

Erik Berglof and Vince Cable

No. 537 | February 2018
Erik Berglof (e.berglof@lse.ac.uk) is a professor and Vince Cable (leader@libdems.org.uk) is a visiting professor, both at the London School of Economics.

This paper has been prepared as background material for the Asian Development Outlook 2017 theme chapter on Transcending the Middle-Income Challenge under the guidance of Donghyun Park.

Berglof (2016) applies a similar conceptual framework to industrial policy in the European Union. 
(c) 2018 Asian Development Bank

6 ADB Avenue, Mandaluyong City, 1550 Metro Manila, Philippines

Tel +632632 4444; Fax +6326362444

www.adb.org

Some rights reserved. Published in 2018.

ISSN 2313-6537 (print), 2313-6545 (electronic)

Publication Stock No. WPS189236-2

DOI: http://dx.doi.org/10.22617/WPS189236-2

The views expressed in this publication are those of the authors and do not necessarily reflect the views and policies of the Asian Development Bank (ADB) or its Board of Governors or the governments they represent.

ADB does not guarantee the accuracy of the data included in this publication and accepts no responsibility for any consequence of their use. The mention of specific companies or products of manufacturers does not imply that they are endorsed or recommended by ADB in preference to others of a similar nature that are not mentioned.

By making any designation of or reference to a particular territory or geographic area, or by using the term "country" in this document, ADB does not intend to make any judgments as to the legal or other status of any territory or area.

This work is available under the Creative Commons Attribution 3.0 IGO license (CC BY 3.0 IGO)

https://creativecommons.org/licenses/by/3.0/igo/. By using the content of this publication, you agree to be bound by the terms of this license. For attribution, translations, adaptations, and permissions, please read the provisions and terms of use at https://www.adb.org/terms-use\#openaccess

This CC license does not apply to non-ADB copyright materials in this publication. If the material is attributed to another source, please contact the copyright owner or publisher of that source for permission to reproduce it. $A D B$ cannot be held liable for any claims that arise as a result of your use of the material.

Please contact pubsmarketing@adb.org if you have questions or comments with respect to content, or if you wish to obtain copyright permission for your intended use that does not fall within these terms, or for permission to use the ADB logo.

Notes:

In this publication, "\$” refers to US dollars.

ADB recognizes "Korea" as the Republic of Korea.

Corrigenda to ADB publications may be found at http://www.adb.org/publications/corrigenda. 


\section{CONTENTS}

FIGURES

ABSTRACT V V

$\begin{array}{ll}\text { I. INTRODUCTION } & 1\end{array}$

II. NEO-SCHUMPETERIAN INDUSTRIAL POLICY AND THE MIDDLE-INCOME TRAP 2

III. STATE CAPACITY AND SPECIFIC INDUSTRIAL POLICIES

IV. RISKS TO INDUSTRIAL POLICY IN EMERGING ECONOMIES

V. RISK MITIGATION THROUGH OPENNESS AND OUTSIDE ANCHORING

VI. TWO SECTOR EXAMPLES OF MODERN INDUSTRY POLICY IN EMERGING 11 ECONOMIES

$\begin{array}{lll}\text { VI. CONCLUSIONS } & 14\end{array}$

$\begin{array}{ll}\text { REFERENCES } & 17\end{array}$ 


\section{FIGURES}

1 Distance to Frontier and Economic Growth

2 Industrial Policies and State Capacity 


\begin{abstract}
We explore the potential roles of industrial policy in the transition from middle-income to high-income status, and the actual experience of industrial policy in emerging economies. Guided by the conceptual framework of the neo-Schumpeterian approach, we look at industrial policy in the context of structural transformation, i.e., in transforming economic structures as well as the institutions supporting these structures. Today's emerging economies face a dual structural transformation challenge: (i) to move closer to the current world technology frontier (traditional catch-up), and (ii) to adjust to technological change in advanced economies and increasingly binding environmental and social constraints. The feasible set of industrial policy is constrained by state capacity. The paradox of industrial policy is that it is most straightforward when state capacity is the most constrained. We suggest that emerging economies still should explore what we denote as sector-based horizontal policies addressing market and state failures in individual industries.
\end{abstract}

Key words: emerging economies, industrial policy, innovation, state capacity, structural transformation

JEL codes: $\mathrm{F} 43, \mathrm{~L} 52, \mathrm{O} 31, \mathrm{O} 38, \mathrm{O} 43, \mathrm{O} 47$ 


\section{INTRODUCTION}

In the wake of the global financial crisis, industrial policy is back with a vengeance in both advanced and emerging economies. Much has been written on the pros and cons of industrial policy, but the fact is that most governments practice it in some form. Even if there is no "industrial policy" as such, decisions on public procurement, for example, for the military or the allocation of research funding effectively creates one.

While, initially, industrial policy was about economic growth and employment, and the expansion of manufacturing in particular, it has been asked to achieve increasingly difficult tasks, including those in the environmental and social space. Industrial policy has been in demand particularly in emerging and developing economies, where they are expected to help countries move closer to the world technology frontier and help them address their social and environmental challenges. Yet, the effectiveness of industrial policy in achieving these objectives depends a great deal on the institutional context and the capacity of the state in a particular country. It is enjoying a renaissance in advanced economies, which have effective governance machineries to promote innovation in deindustrializing societies. Paradoxically, industrial policy seems most important and straightforward where institutions are the weakest, i.e., in contexts far away from the world technology frontier where adopting and adapting existing technologies, rather than genuine innovation, are the name of the game.

In this paper, we want to understand the potential roles of industrial policy in the transition from middle-income to high-income status and the actual experience of industrial policy in emerging economies, with a particular emphasis on the experience from emerging Europe. Guided by the conceptual framework of the neo-Schumpeterian approach (Acemoglu, Aghion, and Zilibotti 2006), we look at industrial policy in the context of structural transformation, i.e., in its role in transforming economic structures as well as the institutions supporting these structures. The focus is on the specific challenges facing emerging economies in catching up with today's advanced economies and on the need for these economies to respond to global challenges; in particular, those related to climate change and social inequalities. There is a danger of industry policy becoming overwhelmed by multiple objectives instead of focusing on productivity and growth. In fact, these economies face a dual structural transformation challenge: (i) to move closer to the current world technology frontier (traditional catch-up), and (ii) to adjust to technological change in advanced economies and increasingly binding environmental and social constraints.

There are, at least, two successful models of structural transformation from middle-income to high-income status. One is the Central and Eastern European model based on broad institutional reforms supported by the outside anchor of European Union (EU) accession and the massive increase in foreign direct investment and capital flows, intermediated mostly by financial institutions with a strategic commitment to the region. The other model is the one that has worked repeatedly in Asia and relies on extensive state coordination undertaken by, more or less, meritocratic bureaucracies, initially protecting firms, and then later promoting domestic and eventually foreign competition. These industrial policies have often been supplemented by national technology projects with varying degrees of success. Within this broad typology, there are major variations notably between the smaller and, more or less, dirigiste economies and the continental sized People's Republic of China and India. And, within Europe, there are varying degrees of integration with the EU and emancipation from economic integration with the Russian Federation-from Eurozone countries like Slovakia and Slovenia, to Ukraine and Moldova. 
The pattern of globalization is now changing and increasingly involves massive amounts of advanced economy know-how being shared with a small number of emerging economies through value chains tightly controlled by corporations (Baldwin 2016). In such a world with fragmented and easily mobile production, advanced economies should focus on "sticky" production factors and positive spillovers that the private sector ignores. Government policy should move from emphasizing industry to service sector jobs related to industry, and promote the development of cities as they attract those kinds of jobs and capture spillovers across value chains. In emerging economies, the fragmentation of production reduces entry barriers. A country now only needs to become competitive in one part of the value chain, not the entire chain. The key objective for governments in the latter countries is to capture the knowledge spillovers and convert them into productivity improvements in other parts of the economy. In both sets of countries, industrial policy should be combined with social policies to deal with the disruptive consequences of structural transformation.

Our focus is on the role of the state in structural transformation, i.e., the capacity and willingness of existing state institutions to manage changes in economic structures and important institutions of emerging economies. We recognize, as emphasized by Rodrik (2014), that we are in a "second-best" world where markets and institutions are far from perfect, which is obviously a more important feature of developing and emerging economies. We will look more closely at a selected number of emerging economies, which made it from middle-income to high-income status since 2000, to understand what role industrial policy played in the structural transformation of these economies. We will focus on the more general discussion of the industrial policy experience, particularly in emerging Europe, and provide some illustrations of industrial policies in emerging economies. At a later stage, when the various case studies have been completed, we aim to undertake a more comprehensive analysis of the specific experiences.

\section{NEO-SCHUMPETERIAN INDUSTRIAL POLICY AND THE MIDDLE-INCOME TRAP}

The core assumptions of the neo-Schumpeterian framework are that, in long-term growth, (i) long-run growth is driven by innovation; (ii) innovations result from entrepreneurial activities; and (iii) creative destruction, i.e., new innovations displacing old technologies, is critical (Aghion and Bircan 2017). An economy can be off the frontier in three different ways: (i) the aggregate of all industries and individual firms in these industries, (ii) the industry average and median, and (iii) each individual firm has its own (average) distance(s) to the frontier(s) in the industries in which it operates. Obviously (i) combines (ii) and (iii), but it also requires an assessment of the relative importance of individual sectors to the overall economy. (iii) is particularly important in understanding emerging and developing economies, where hetereogeneity is particularly striking and where technologically advanced firms and many emerging economies have at least a few such firms (Freund 2016) that can exist alongside very backward firms - distributions of firms by productivity have long and fat tails and distorted firm dynamics. An important challenge for industrial policy in these economies is to compress the distribution of firms in terms of distance to frontier by closing down or upgrading slacking firms, and transferring resources from uncompetitive sectors. Of course, upgrading leader firms (shifting from imitation and/or adaptation to innovation) is also necessary. Most recommendations have focused on sector-based policies. The problem is that sectors do not produce and trade firms do, and there is considerable heterogeneity within sectors, meaning that specific industrial policy measures may have very different implications for individual firms.

The implications of the neo-Schumpeterian approach for industrial policy in emerging economies off the world technology frontier are that (i) increased competition is not necessarily positive for productivity growth, as it might undermine the incentives for innovation provided by 
intellectual property protection and monopolies maximizing economies of scale; (ii) coordination has a high premium as it helps achieve economies of scale; (iii) financial mobilization should happen through banks or vehicles for mobilizing venture and other risk capital rather than financial markets; (iv) while education is important at all stages of development, secondary and tertiary education are particularly important off the frontier (while postgraduate education may actually be a waste of resources); (v) protection of intellectual property, openness, and competition are complements and, as such, more important at the frontier; (vi) similarly, entry barriers and corruption are more important the closer an economy is to the frontier (this is, of course, not meant to condone corrupt practices-corruption is almost always a symptom of bad policy-but it matters more as an economy approaches the frontier.); (vii) technology transfers should be a focus (but technology must be appropriate, in the sense that it contributes to productivity improvements); (viii) management skills are very important (Bloom and van Reenen 2007); and (ix) strong efforts should be made to reallocate factors of production, across firms and industries, to more productive uses. The levers can be activated both directly and also indirectly by reducing corruption, relaxing credit constraints, and improving education quality.

As an economy reaches the world technology frontier, the importance of competition and its complements increases and the emphasis shifts from imitation and adaptation within existing firms to innovation through the entry and exit of firms. Financial markets gain in importance relative to banks in the financing of innovation, and tertiary and postgraduate education become more important.

A core contribution of the neo-Schumpeterian framework to the discussion of industrial policy is the conceptualization of the "middle-income trap" around the "switching point" from an industrial policy optimal away from the frontier to one that is suited for when an economy is close to or on the frontier (Figure 1). There could be many forces frustrating this switch. The most commonly discussed is one associated with special interests and political economy, where incumbents and insiders block the emergence of institutions necessary to support a frontier industrial policy or just outright block the decisions associated with the switch itself. But there could also be rigidities in, for example, human capital formation or financing arrangements that make switching more difficult. An industrial policy must take the existence of a switching point into account and incorporate features that would help facilitate this transition. In other words, some specific transitional policies may be needed as an economy approaches the switching point to increase the likelihood of the switch.

Figure 1 illustrates the notion of a middle-income trap conceptually. The horizontal axis captures total factor productivity in a particular country relative to the frontier at time $\mathrm{t}-1$ and the vertical axis shows the same ratio at time t. Take a country at a time, for example, the PRC in 1990, assumed to grow mainly through investment (investment-led growth). Initially, the returns to additional investment in terms of growth are high, ensuring that the economy moves closer to the frontier, but over time these returns come down and at some point, here assumed to be before 2016, shifting toward innovation-led growth will ensure faster catching-up, and some later time the line for investment-led growth crosses the 45 degree line, suggesting that there is no more catch-up (what we define as the middle-income trap). The optimal switching point was here assumed to be before 2016, but the country's institutions may be hard to change to achieve the necessary structural transformation and at the point where the middle-income trap sets in the old growth model has run out of steam.

In this imaginary example, Chinese institutions with their legacy from central planning and emphasis on heavy industry worked well when investment-led growth was optimal, but they may find it difficult to adjust to innovation-led growth. In 2016, the economy may already have passed the optimal switching point, but many features of the PRC's industrial policy may still be better suited for a country 
far away from the frontier. In fact, the PRC government has already adopted many frontier policies, and the evidence, for example, on value added in many industries, suggests that the transition is already well under way.

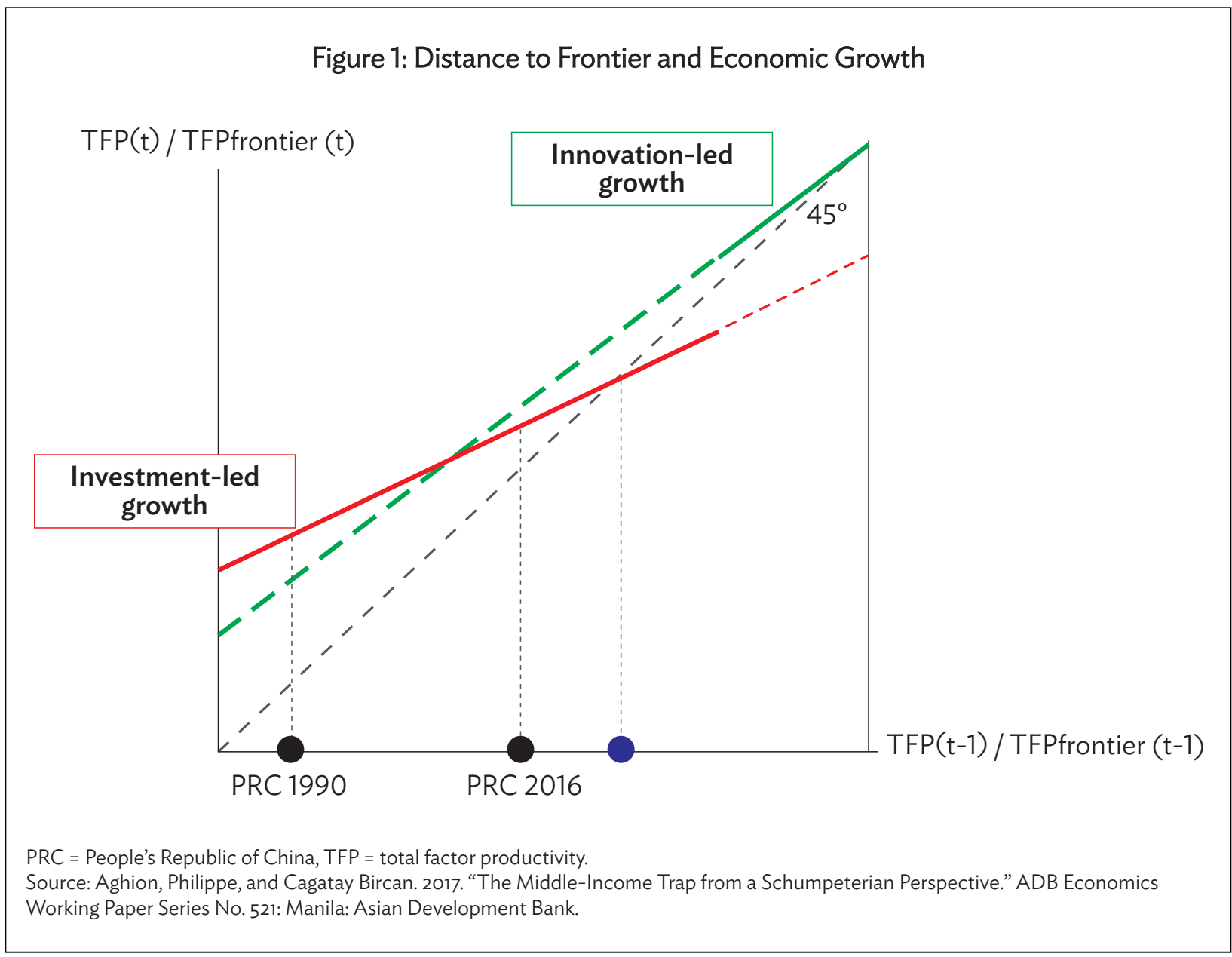

\section{STATE CAPACITY AND SPECIFIC INDUSTRIAL POLICIES}

An important consideration in assessing what type of industrial policy a particular emerging economy could and should pursue is its ability to implement and enforce specific policies, and whether it has sufficient checks and balances preventing policies from being captured by special interests; in other words, whether there is a politically independent system for evaluating projects and agencies with sufficient autonomy to decline or terminate politically sponsored but bad projects. Are there particular institutional traps that pertain to industrial policy and that could undermine progress in other policy areas? We will discuss the risks of different approaches and what can be done to safeguard against abuses, combining conceptual analysis and an examination of emerging economy experiences.

There are other important implications from the fact that we are working in a "second-best" world. The case for industrial policy is premised on the existence of market failures that require government intervention, for example, a subsidy. Analytically, this is often done in the context of economic models where there is only one market failure in the economy. Of course, emerging economies are full of distortions, such as labor market regulations, and energy subsidies. Often, the 
success of a particular industry is based on the suppression of others. For example, India's information technology sector is believed to have grown because the manufacturing sector was constrained by labor regulations and poor infrastructure. Energy subsidies in many emerging economies have created export sectors and strong constituencies reliant on cheap energy. In this case, the focus of the government should be on getting rid of the energy subsidy before it tackles the other challenges. If energy subsidies, for some reason, cannot be removed in the near term, focus needs to shift to other important constraints.

The most ambitious industrial policy seriously discussed is probably that of the "entrepreneurial state" (Mazzucato 2013). This approach sees the state as a mission-oriented "venture capitalist" taking important risk in individual sectors and firms, and using a portfolio approach to diversify that risk, while trying to retain a level playing field in individual sectors. The model has perhaps most clearly been expressed in various innovation schemes sponsored by the Government of the United States (US), but another example is the Israeli state-sponsored Yozma program, which launched an eventually very successful venture capital industry, now essentially privately owned. The state would set the direction of travel of individual industries and provide road maps, preferably through sector dialogues. One important aspect stressed by the proponents of this approach is the need to improve assessment tools and encourage evidence-based learning to facilitate structural transformation. Under this approach, the state has a role in developing markets, for example, feed-in tariffs, in order to allow the market for renewable energy to develop.

The "entrepreneurial state" would also crowd in private capital, particularly institutional capital, to mitigate coordination failures achieve critical scale (for example, the Brazilian Development Bank [BNDES], also known as the National Bank for Economic and Social Development). This form of industrial policy is easily captured and, as such, very demanding on institutions and sensitive to political risk (as seen, for example, in the renewable energy industry, both in emerging and advanced economies). The potential and the risks involved in such ambitious industrial policy are illustrated by the two US examples of Tesla - at least until recently regarded as a great success - and Solyndra, which became a huge embarrassment for the Obama administration when it failed.

To understand that industrial policy is desirable and feasible in a particular economy, we need some concept of state capacity, i.e., the institutional capability of the state to carry out policies that deliver benefits and services to households and firms (Besley and Persson 2011). Different industrial policies place different demands on state capacity, and some aspects of a particular industrial policy are likely to be more demanding than others. An industrial policy should not be seen in isolation, but it should also be part of a broader program to achieve environmentally sustainable growth, emphasizing equality of opportunity or, for that matter, building up greater domestic competence for security reasons. Particular industrial policies are dependent on particular aspects of the institutional environment. This type of complementarity is important throughout the development process, but which aspects should reinforce each other are likely to differ from one development phase to another.

Most of the work on state capacity has been concerned with low-income countries and focused on which institutional characteristics determine this capacity. Besley and Persson (2011) talk about what they call "development clusters." Paraphrasing Tolstoy's Anna Karenina, they state that "all prosperous countries resemble each other; every non-prosperous country is non-prosperous in its own way." They find that countries, in their transformation from low income to middle income, are becoming much more similar on the dimensions of their framework. Our main concern is what needs to happen to countries as they proceed from middle to high income. What are the relevant differences among middle-income countries determining whether one country will move toward high income and 
another getting stuck as a middle-income country? In what dimensions are successful economies becoming more similar, and where do they remain different without seemingly affecting their transformation to high-income status? Conversely, what institutional constraints seem to be particularly important in explaining why certain countries are successful and others not?

More precise statements about what industrial policies are implementable in a particular context require more granular descriptions of state capacity and what determines this capacity. Fortunately, we have a relatively recent natural experiment with a number of countries transitioning from middle income to high income at approximately the same time, i.e., the EU accession process in Central and Eastern Europe. Separately, we have the achievements of the Republic of Korea; Singapore; Taipei,China; and, more recently, the PRC (or parts of it). Bruszt and Campos (2017) look at the yearly assessments by the European Commission of these countries to understand the interaction between various aspects of state capacity and the sequencing of institutional development. They identify three aspects of state capacity: the judiciary, the bureaucracy, and competition policy. Under each of these, they distinguish between independence and capacity, and then look at the interrelationship between the different elements. Using lagged variables, they also look at the sequencing of institutional development and suggest that judicial capacity and ultimately judicial independence, i.e., the establishment of a constitutional supreme court, are essential to bureaucratic capacity and the enforcement of competition policy. They demonstrate an intricate relationship between bureaucratic independence and judiciary capacity in unleashing a virtuous spiral of institutional change.

Taking the findings of Bruszt and Campos (2017) to industrial policy, the implication is that a certain bureaucratic independence and judicial capacity are necessary even for the simplest and most straightforward horizontal policies. These aspects of state capacity, in turn, trace back to judicial independence. Industrial policies that demand more from state capacity will require even more independence from the bureaucracy and greater capacity of the judiciary. The strong suggestion is that more demanding industrial policies may not be feasible until later stages of institutional development when state capacity is greater (Figure 2).

One way to discipline industrial policy when domestic institutions are fragile is by entering into international agreements constraining policy makers. The most advanced such arrangement is the EU. A large number of emerging economies have joined the EU in its southern and later eastern enlargement. EU rules clearly constrain state aid policies and competition and trade policy more generally, and have helped these countries commit to policies and limit capture. The currently discussed, and now politically dead at least in their original configurations, "mega trade deals" (TransPacific Partnership and Transatlantic Trade and Investment Partnership) embrace other ways to limit the capacity of individual governments to favor specific sectors or introduce barriers to trade. We will discuss the extent to which these deals support or possibly undermine effective industrial policy.

There are many ideas in circulation for how the state can support structural transformation, transcending the traditional distinction between the universally embraced horizontal policies and the more controversial vertical policies. There are a number of intermediate approaches which could be characterized as sectoral-based horizontal policies, for example, supporting human capital improvements, financing conditions and innovation in a particular industry, but also at so-called "smart specialization" encouraging traditional industries as agricultural and textile manufacturing to invest in information and communication technology or biochemistry. An important related strategy starts from the observation of the growing importance and fragmentation of global value chains, and how industrial policy can be used to facilitate the entry of firms into these global chains (Baldwin 2016). 
Once the focus is on benefiting from being part of these global production systems, broad sectorbased policies may be less effective as only part of the value chain will be based in a particular country. Instead the emphasis should be on attracting those parts of the value chains which have high (positive) spillovers, possibly to attract other value chains.

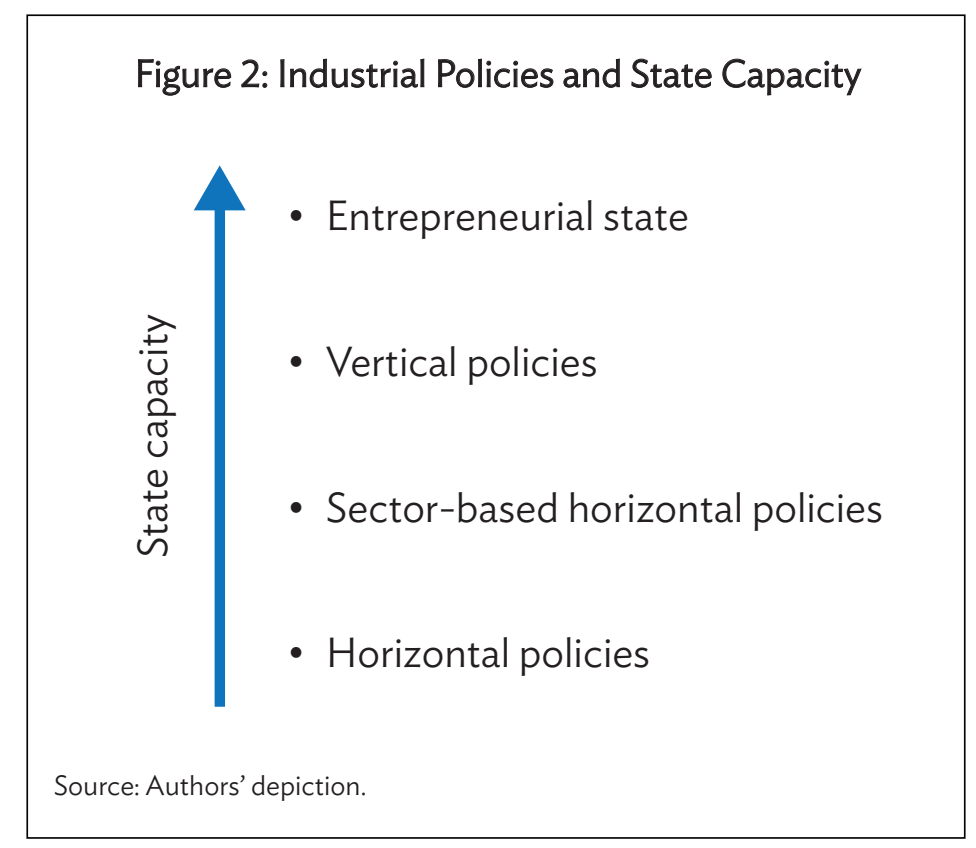

\section{RISKS TO INDUSTRIAL POLICY IN EMERGING ECONOMIES}

There are a number of risks to industrial policy. While they apply universally, they are all related to weaknesses in state capacity and, as such, more pronounced in emerging and developing economies.

Political capture. The most commonly discussed and best understood is the risk of political capture. There are many instances of industrial intervention being captured by vested interests which distort it for their own purposes. The "Washington Consensus" disfavoring industrial policy and "picking winners" was based on a large body of experience to the effect that such policies frequently supported "rent seeking" rather than innovative behavior by companies.' Recent work on Egypt and Tunisia provides ample examples of such capture and how special interests distort regulation, undermine enforcement of competition policy, as well as channels direct support to specific firms with highly detrimental effects on firm dynamics (Diwan, Keefer, and Schiffbauer 2013). In Tunisia where "Ben Ali firms" - connected to the former president's family-accounted for $1 \%$ private sector output and $3 \%$ of employment, but had $21 \%$ profits (and contributed negatively to the cost competitiveness of the country's exports by exercising monopoly power over pricing). There are many such examples across the Middle East, Asia, Africa, Eastern Europe, and Latin America and the "Ben Ali" story could plausibly be told of many countries where cronyism and corruption distort decision making.

\footnotetext{
The Washington Consensus refers to a set of broad ideas for how to reform economies, supported by prominent economists and international organizations, such as the International Monetary Fund, the World Bank, the EU, and the US. Essentially, the Washington Consensus advocates free trade, floating exchange rates, free markets, and macroeconomic stability drawn from 10 principles and policy recommendations originally stated by the British economist John Williamson in 1989. These principles have since been revised and refined, particularly providing a more nuanced stand on issues such as privatization and a greater emphasis on institutional development.
} 
But we need to be careful of lazy generalizations. The Middle East has been a fertile ground for "Ben Ali firms" in almost every country. But there are important exceptions. The transformation of Dubai into one of the world's leading aviation hubs was widely ridiculed at its inception and has, no doubt, involved a fair degree of cronyism and waste (Dubai had to receive financial assistance from Abu Dhabi a few years ago), but a successful transformation has been achieved. Turkey has, under successive governments, been criticized for favoring entrepreneurs in some sectors through discretionary industrial assistance, especially import licences. But Turkish construction contractors and consumer durable manufactures have now become major, internationally competitive, suppliers in those sectors.

More generally, it is often argued that the risk of political capture will be minimized in open, democratic systems, which can expose malpractice and political interference with business decisions. Unfortunately, that is often not the case. Chang (1993) describes the way in which Korean firms were persuaded in the 1960s and 1970s to disregard their commercial judgements in favor of priorities chosen by military and bureaucratic decision makers by a process which could involve "a quiet chat with the secret police." These "quiet chats" have helped to produce world-beating companies in consumer electronics, steel, shipbuilding, and heavy engineering. And many contemporary positive examples of "picking winners" are in the PRC, which does not have transparent democratic systems. For example, Chinese firms, many state owned, have developed an ascendency in the technology and manufacture of solar power equipment systems; the result of a deliberate policy choice to specialize in this sector among a range of renewable energy options (in contrast to the US and the United Kingdom (UK), which deliberately eschewed "picking winners" and have seen renewable energy industries flounder because of inconsistent or inadequate support). Singapore's industrial policy is widely recognized as sophisticated, forward looking, market sensitive, and free of corruption-and now extends to creative industries like design. But there is little democratic political challenge.

Nor are more democratic transparent political systems necessarily more effective in identifying, and holding to account, unproductive rent-seeking activities by industrial interest groups. Democratic India, in one survey, had $25 \%-40 \%$ of gross domestic product consumed in the rentseeking costs of protective trade policies (Hamilton, Mohammad, and Whalley 1984). There is now a substantial body of academic research which explains lobbying behavior in democratic systems. It suggests that it will be most effective when there is large industry, a small number of companies involved and where the industry is in decline, is labor intensive and facing import competition (Anderson and Baldwin 1987). In other words, more damage is likely to be done in defence of struggling "losers" rather than pursuing potential "winners."

A more subtle distinction is needed than that between "authoritarian" and "democratic" systems to explain why industrial policy can lead to wasteful and damaging political capture in some instances but not others. Brazil is very familiar with "clientelism" and corruption (as we have recently been reminded), but has produced a (government owned) aircraft manufacturer (Embraer) which competes in (small and mid-sized) international markets for jet aircraft and is the third largest globally after Airbus and Boeing (roughly tied with Bombardier). Indonesia, on the other hand, produced a classic "white elephant" when President Suharto's vice president (B. J. Habibie) sought to launch Indonesian aircraft manufacture. The company went bust, after losing a lot of money, in the Asian financial crisis (but has been reborn as part of the Airbus supply chain).

Another surprising contrast is that India now exports more passenger cars than the PRC despite the PRC's overwhelming superiority in manufactured exports generally (India exported 532,000 vehicles in 2015/2016 to the PRC's 410,000). Yet the modern car industry in India was 
launched as a highly political vanity project (by Indira Gandhi's elder son, Sanjay, who launched the Maruti in the mid-1970s; the Maruti is now one of the leading exporters). It has succeeded (relatively) by making judicious use of foreign alliances and investment (while the PRC has used foreign investors to supply the high end of the domestic market). Both the PRC and India are, however, massively outcompeted, so far, by Japan, the Republic of Korea (and even Thailand), which "picked the car industry as a winner" a generation earlier.

Stretching the envelope of adaptability even further is the space industry. Soviet space exploration was, perhaps, the ultimate in politically driven, wasteful activity. Prestige and military prowess, not economics, lay beyond Soyuz and Sputnik. Yet in post-Soviet Russia (and Kazakhstan) the space industry survives. Russian rockets and space facilities are a key part of today's commercial space industry, ferrying (inter alia British and Indian) satellites into orbit for communications and data collection purposes. The mutual-and commercial-benefit is such that the partnership has escaped sanctions on the Russian Federation.

All these examples, even those that have turned out well, raise the obvious question of what was the "opportunity costs" involved in promoting them. In some cases, the cost of protection or subsidization was very long standing; Brazil's aircraft industry was first launched 65 years ago. These opportunity costs are, however, now bygones (unless embedded in future debt obligations). And what these examples tell us is that "political capture" may be less important than the ability of the "captured" companies and the state which has sponsored them, to learn from experience and adapt to international conditions rather than to sit on monopoly profits. This process may take a long time and the skill or art behind industrial policy may be one of learning how to build in competitive challenge and performance management over the long term.

Information asymmetries. A further, and related, risk is the asymmetry of information between a firm operating in a market with access to price and quality signals, and government officials and politicians making decisions from a position of ignorance. Some of the more egregious examples of failed industrial policy involved "turnkey" operations in which a state agency or protected company in a developing economy takes on the risk of operating a complex technology and equipment without fully understanding them and without the capacity to operate, maintain, and develop them further.

Chang (1993), however, drawing on far eastern experience in particular, dismisses the "information asymmetry" argument. He questions whether businessmen, close to their own businesses, are necessarily better informed, especially where we are concerned with future trends and new technologies. There are numerous examples of bad decisions made by private companies, big and small (for example, the evidence showing that takeovers are, on average, value reducing for the predator company). Business people are, of course, using their own (or their shareholders' and creditors') money rather than the taxpayers', but that then resolves into a question of government's ability to negotiate risk sharing rather than its ability or inability to "pick winners."

Moreover, there are ways in which governments can ensure that they are well informed through information exchange with business partners, or through setting up reporting mechanisms as part of accountability for state support, through operating state-controlled entities, which learn how to operate in the market place by acquiring the necessary information. All of this assumes that there are public servants (or state entrepreneurs) sufficiently capable and motivated to perform that role and, clearly, there are widely different performance levels within and between countries. But learning behavior applies here too. 
Government failure. The risk central to active industrial policy is whether government failure is bigger and more costly than market failure. In the development of trade theory, the Mill/Barnstaple conditions for justifying industry protection formalize this requirement, that the benefits of intervention outweigh the costs. In the real world, it is difficult to make this kind of assessment ex ante rather than ex post and as some of the examples above illustrate. Successful industrial policy involves learning and adaptive behavior, which comparative static methods of project evaluation do not capture. Industrial policy is, also, trying to do something difficult and often more ambitious than business would ever attempt. The story of Korean or Chinese industrial policy is of long-term transformation, which would never be attempted commercially. There is, almost by definition, a high risk of failure, but it is failure of a different kind (and scope) than conventional business decisions.

There is, however, a particular risk that, in a second-best world replete with distortions, a particular intervention in the name of industrial policy may make matters worse. For example, protection of the steel industry, if it raises costs, may undermine the domestic metal using industries. These negative effects may also work out across sectors as well as within them. A common problem in the Organization of the Petroleum Exporting Countries has been that, because oil or gas is sold domestically at prices below world market levels, industrial policy may involve investment being pulled into energy-intensive industries rather than others, which may have a greater transformational capacity. Industrial policy is more likely to succeed where such distinctions are neutralized or recognized and discounted.

\section{RISK MITIGATION THROUGH OPENNESS AND OUTSIDE ANCHORING}

Industrial policy suffers from a fallacy of composition problem. What works for one country may fail if other countries try to do the same, or impose restrictions on goods and services which the interventionist economy seeks to export. We regard the Republic of Korea as a poster boy of successful industrial policy, but its success depends in large measure on other countries being ready to import Korean ships, steel, and cars, even where this means a contraction in their own competing industries. The rules of international trade have to be accommodating. So far, the rules of international trade law, which guard against subsidy and "dumping," have been observed and the dispute settlement panels of the World Trade Organization provide a quasi-legal backstop to the system. There are, as we know, strong demands, in the US especially, to tear down this institutional architecture in the interests of more nationalistic approaches. So far, this has not happened, but the signs are that the Trump administration is aiming to deconstruct at least part of the international trade regime.

The EU is, by far, the most advanced regime for deep economic integration. At its inception, the European Community was built around sectoral industrial policy for coal and steel, albeit one which recognized the need for European-level rationalization. The common agricultural and fisheries policy was also sector based and highly protectionist and, in Vinerian terms, trade diverting, at least initially. Various member state governments and individuals have sought, over the years, to create EUwide industry policy for future winners, but these have not got very far, with the possible exceptions of cross-border aerospace collaborations like Airbus and Eurofighter.

Since the agreement to create a single market, in the 1980s, the main thrust of EU policy has been to create rules to facilitate and police free trade within the EU rather than to accommodate active industry policy at national or EU level. Now, the main facilitating mechanism is the adoption of common or mutually recognized technical product and professional standards, a form of market-based industrial policy which nonetheless retains or intensifies competition. The constraining measures 
include common public procurement rules to prevent discrimination between suppliers from different member states (though, as we have seen from the Government of France's intervention at Belfort, preordering trains, these rules can be ignored or circumvented); competition policy rules which challenge takeovers and monopoly at EU level (it is difficult to think of many examples, outside of aerospace, of European "champions" emerging as a result of cross-border merger activity); and state aid rules which police explicit or implicit subsidization of companies at a national level (particularly fierce in steel and coal where there is EU excess capacity overall). The combined effect of these market-based measures has been to inhibit active industrial policy in countries (like France) which have wished to pursue it and to channel intervention into more "horizontal" policies (including infrastructure provision, training, and broad-based research and development) or more creative ways of attracting specific, sector-based investment as deployed in some Eastern European countries (or regions of other members, as with Scotland, Wales, and Ulster).

The mooted Trans-Pacific Partnership and Transatlantic Trade and Investment Partnership agreements are attempts to capture some of the benefits of the EU single market among countries which start from lower levels of integration. In both cases, however, there has been a strong political reaction against deeper integration and neither seems likely to progress, particularly after the outcome of the Brexit referendum and, more importantly, the election of Donald Trump as the US President.

There is, however, one form of international agreement which is prompting active industrial intervention. Various climate achievements require of their adherents a commitment to low carbon technologies which, except in a few cases, are not currently competitive with fossil fuels though they have falling cost curves. There are essentially two approaches to this problem. One, theoretically superior, but practically difficult, measure is to establish a carbon price, which reflects an assessment of the externalities of global warming and which is levied on energy use through a carbon tax. The other approach is to concentrate support on one or two favored technologies which are judged (on the basis of independent, scientific advice) to have the best potential for the country concerned. Chinese solar power is a good model. Panels are now mass produced driving down costs, enabling the PRC to export to the extent of market dominance: a case of strategic industry protection turning the terms of trade in its favor. Similarly, Brazil has made a long-term commitment with biomass, used for motor vehicle fuel, though it has been exposed to greater criticism on environmental and economic grounds.

\section{TWO SECTOR EXAMPLES OF MODERN INDUSTRY POLICY IN EMERGING ECONOMIES}

We shall look at several examples of middle-income countries trying to develop sophisticated versions of industrial policy, which try to learn from past policy failures and good practice. We will look at a couple of industries and some country examples.

Automobile industry. One industry where industrial policy has played an important role is the automobile industry. Most emerging economies, of any size, have sought to promote a domestic car industry, and this sector produces some of the worst (and a few of the best) examples of infant industrial policy applied in manufacturing. There are many variants, but they can be rationalized into three idealized models.

The first is the classic import substitution route starting with assembly kits of different global car models behind protective tariffs or quotas, and then seeking to build up a domestic supply chain by forcing or incentivizing the manufacturer-typically one of the leading European, US, Japanese, or

Korean producers - to build up local content. The costs of this approach are well documented and are 
borne by domestic consumers (or taxpayers in the case of subsidy): inefficient, subscale operations resulting in a big gap between domestic and international prices; and disincentives to export unless mandated and cross subsidized as part of an agreement with a global company.

This route nonetheless remains the favored route, especially for countries which have a large domestic market (the PRC, for luxury vehicles; India; Brazil, which is now a major producer of Volkswagen; South Africa; Nigeria; Saudi Arabia; Iran; and the Russian Federation), and even some developed countries (Australia, Canada). In fact, before the recent downturn in the economy, the Russian Federation was producing more cars than Germany.

The second is the deeper and more ambitious strategy of developing an "indigenous" car. Several developed economies (the UK, Germany, France, and Italy) saw domestic entrepreneurs drawing on a long tradition of engineering and innovation in the sector to build up large-scale mass production by recognized national brands. In several cases, nationalization or overt state support was used to promote domestic producers (Volkswagen, Renault, and Fiat). Several Japanese industrial keiretsu (Honda, Toyota, and Nissan) developed the industry rapidly in the postwar era with domestic supply chains and achieved scale through large-scale exports. The Republic of Korea followed suit and is now a major exporter. Yet, the Republic of Korea also illustrates the limitations of this approach. When the Asian financial crisis hit the Republic of Korea, it exposed the financial weakness of the leading car producers, which lagged behind the US, Japanese, and European companies in adopting the potential of international supply chains, including components made in low-cost locations, like the PRC (Baldwin 2016). Leading producers collapsed and were taken over by General Motors and Renault. Only Hyundai survived as a Korean company, and it adapted to the new business model based on internationally integrated supply chains.

Other efforts to achieve an "indigenous" car have been even less successful. Malaysia developed Proton based on a Japanese model, but failed to achieve viable levels of production. In sharp contrast, Thailand made no attempt to develop an indigenous car, but offered an attractive business environment and low labor costs to component suppliers within global supply chains. Thailand is now a major car exporter as is Viet Nam which is following a similar strategy. To take another example, the Trabant was quite modern when introduced in 1957 in East Germany, and in the absence of western competition it became a mass-produced car, but by the time of the fall of the Berlin Wall in 1989, it had become a laughing stock for its failure to innovate (another Eastern European car, Skoda, has now flourished as a subsidiary of Volkswagen). The Indian automobile manufacturer Maruti had to be partly taken over by Suzuki, which has turned it into a modestly successful exporter. The PRC has several indigenous car companies, but they produce for the lower end of the domestic markets so far. This route has the potential to generate the maximum in terms of backward linkages and value addition from research and development and design work. But, in the absence of scale and a large investment in marketing, technology, and skills, the potential for heavy costs is also real with the likelihood that there is no prospect of becoming internationally competitive in a world of internationally integrated supply chains. As part of the Government of the PRC's policy to encourage technology acquisitions overseas, the domestic carmaker Geely bought the Swedish higherend passenger carmaker Volvo in 2010.

A third model is quite different. Essentially it involves inserting the country into the supply chain of multinational companies to export. Mexico in North America; Hungary and Slovakia in Eastern Europe; and parts of the PRC, Thailand, and Viet Nam have attracted tier 1 or tier 2 supplies to the US, German, and Japanese car industries by establishing cost competitiveness based initially on low wages but also improving productivity. There is, at this stage, no commitment to integrate backwards into a 
fully developed car industry, but skills are being transferred and domestic supply chains built up. There may be an element of subsidy at the start-up stage, but this approach best ensures that decisions are made based on international prices and quality with minimum levels of protection. But, at the same time, there is the risk of supply chain disruption and reshoring.

Creative industries. A contrasting case and one which, at first sight, sits a little oddly in "industry policy" is that of "creative industries." The boundaries here are a little fuzzy and range from information and communication technology to content-the how as well as the what. Content industries range from commercialized arts like music, architecture, and advertising to fashion, design, and film. Recognition of the economic importance of creative industries came in the Uruguay Round of trade negotiations in the 1990s when the US prioritized "Hollywood" and the issues of copyright. India exports considerably more in the form of information technology services, crafts, and "cultural goods" (film and music) than it does agricultural or manufactured goods. Just as the band ABBA became a major Swedish "export" other poorer countries have been able to commercialize their creativity.

"Creative industries" are inherently unpredictable. Fashion changes. Technology is disruptive. This might seem improbable territory for industry policy. Nonetheless, there are, or can be, significant market failures. Many of the skills involved in, say, design are multidisciplinary and transferrable, not normally vocational, and require educational planning. There are many examples of the externalities derived from clustering of creative industries and this can be facilitated; financial institutions will, commonly, not lend against intellectual as opposed to physical property without special credit schemes. It is significant that Singapore, often a source of good practice in industry policy, launched a 10-year strategy to improve the country's competitiveness in design (Design 2025). It organizes competitions and exhibitions as well as supports training. The Republic of Korea has adopted creative industries as a major long-term strategic priority seeking to establish Korean brands in music, television soaps, design, and fashion. The PRC has done the same in a less systematic way, though the city of Qingdao is becoming the center of efforts to create a Chinese Hollywood or even Bollywood. The Chinese "culture industry" is planning to become a major player in this sector. At a less sophisticated level, many of the poorest countries are seeking to add value to traditional crafts by improving design and marketing, and establishing brand recognition and copyright.

The UK and the Republic of Korea have tried in a systematic way to promote "creative industries" as an internationally tradable service industry by addressing weaknesses in credit supply, intellectual property law, and training and communication infrastructure. The risk of policy failure is higher since technology and markets are changing rapidly, but the opportunity costs are lower than in capital-intensive activities and the value addition potentially large. Also, distance from markets is less of an issue, which is why internationally traded creative industries have an appeal in remote Russian cities or in India where the physical infrastructure of ports and roads is poor; provided Internet connectivity is good. 


\section{CONCLUSIONS}

The neo-Schumpeterian framework, combined with the literature on state capacity, has helped us understand the actual and potential roles of industrial policy in different contexts. In particular, this perspective sheds light on the differences in the desirable policies when an economy, an industry, or a firm is at the world technology frontier and when it is far from that frontier. But the literature on state capacity also suggests that what the appropriate policies are depends on what the institutions can handle. Very importantly, state capacity is tested around the point where it is optimal to switch from one set of policies to another. This switching point is the key to understanding how to avoid getting stuck with inappropriate institutions and policies - what we have defined as the middle-income trap without tying it to a specific income level or even claiming that, empirically, countries get stuck at particular income levels.

We have looked at two successful models of structural transformation allowing countries to go from middle-income to high-income status: one in Central and Eastern Europe based on broad institutional reforms supported by the outside anchor of the EU accession process and the massive increase in foreign direct investment and capital flows intermediated mostly by financial institutions with a strategic commitment to the region; and one that has worked repeatedly in Asia and relies on extensive state coordination undertaken by, more or less, meritocratic bureaucracies initially protecting firms, and then later promoting domestic and eventually foreign competition. These industrial policies have often been supplemented by national technology projects with varying degrees of success.

A core question is whether these two models are truly distinct, relying on their own inherent compatibility between different aspects of their institutional arrangement, or whether in fact they share certain common features. In looking for such potential common features, it seems that state capacity is critical. In Central and Eastern Europe, this capacity was built in a short space of time and with strong support from the outside. In Asia, state capacity emerged more organically, and core features such as strong meritocracy dates back far. But, under the American occupation after World War II, there was considerably external intervention in the Japanese bureaucracy (Johnson 1982) and, in the Korean Peninsula, the trans-Pacific anchor of the Republic of Korea most probably played an important role in explaining the divergence of the Republic of Korea and the Democratic People's Republic of Korea (Acemoglu and Robinson 2013). Yet, institutional quality also matters greatly in Asia, and it is very hard to see that the sophisticated policies that have been so successful in, for example, Japan; the Republic of Korea; Singapore; and Taipei,China would have the same positive results in Asian countries with weaker institutions. On the contrary, there would be great risks in transferring these approaches and tools to such environments without proper institutional reforms.

At the core of the assessment of the desirability and feasibility of industrial policy in different contexts is what we have called the "paradox of industrial policy," where industrial policy seems most palatable and justified. When economies are imitating and adapting existing technologies, institutions tend to be the weakest. The approach also makes us skeptical of the frequent advice that more competition is always desirable as it undermines the rents from innovation and may cause individual firms and industries, and ultimately entire economies, to move further away from the frontier. In other words, horizontal policies focusing single-mindedly on competition may be counterproductive. Firmspecific vertical policies, and even more so the "entrepreneurial state" approach, are more susceptible to capture and more vulnerable to political risk and potentially to other forms of uncertainty. We provided a number of examples from state capture and political risk in emerging economies. 
Sector-specific horizontal policies are less demanding on institutions, but still vulnerable to uncertainty (global value chain policies could become obsolete and smart specialization too "domestic"). Combining the two approaches is a promising way to proceed, and we gave some examples of countries where this has been successfully pursued in Central and Eastern Europe. However, sector-based approaches are becoming obsolete in many industries as trade and investment flows, and the associated transfer of knowledge increasingly happen within global value chains, fragmented across countries, and controlled by individual corporations. Industrial policy is increasingly about attracting parts of these value chains-something that has become easier as a result of their fragmentation-and exploiting the knowledge spillovers from them. Importantly, industrial policy will increasingly be about services, rather than manufacturing.

Policies that require strong state capacity could possibly be made feasible if they were to be disciplined by "outside anchors" (EU accession and deep trade agreements such as the Trans-Pacific Partnership). We discussed briefly the sequencing of the building of state capacity in the experience of Central and Eastern Europe. Clearly, building bureaucratic capacity is core, but we also saw that judicial capacity is important for the enforcement of, for example, competition policy. The analysis pointed to areas where resources should be focused in order to strengthen both judicial and bureaucratic capacity.

The overall conclusion is that emerging economies are probably best served by a mix of sectorbased horizontal policies combined with specific policies on technology transfers, often involving attracting parts of value chains with large spillovers. We provided some successful examples in Central and Eastern Europe and Asia, combining sector innovation support, connection to global value chains, and upgrades of information technology in a general environment of openness to outside anchors to domestic reform process like EU accession in Central and Eastern Europe and a potentially revised Trans-Pacific Partnership for Asia. 


\section{REFERENCES}

Acemoglu, Daron, Philippe Aghion, and Fabrizio Zilibotti. 2006. "Distance to Frontier, Selection, and Economic Growth.” Journal of the European Economic Association 4 (1): 37-74.

Acemoglu, Daron, and James A. Robinson. 2013. Why Nations Fail: The Origins of Power, Prosperity, and Poverty. Crown Publishing.

Aghion, Philippe, and Cagatay Bircan. 2017. "The Middle-Income Trap from a Schumpeterian Perspective.” ADB Economics Working Paper Series No. 521: Manila: Asian Development Bank.

Anderson, Kym, and Robert E. Baldwin. 1987. "The Political Market for Protection in Industrial Countries." In Protection, Cooperation, Integration and Development, 20-36. UK: Palgrave Macmillan.

Baldwin, Richard. 2016. The Great Convergence - Information Technology and the New Globalization. Cambridge: Harvard University Press.

Berglof, Erik. 2016. “European Industrial Policy-Tapping the Full Growth Potential of the EU.” Review of European Economic Policy 51 (6): pp. 335-40.

Besley, Timothy, and Torsten Persson. 2011. Pillars of Prosperity: The Political Economics of Development Clusters. Princeton University Press.

Bloom, Nicholas, and John van Reenen. 2007. "Measuring and Explaining Management Practices across Firms and Countries." The Quarterly Journal of Economics 122 (4): 1351-408.

Bruszt, Laszlo, and Nauro Campos. 2017. "Deep Economic Integration and State Capacity: The Case of the Eastern Enlargement of the European Union.” Manila: Asian Development Bank. Unpublished.

Chang, Ha-Joon. 1993. "The Political Economy of Industrial Policy in Korea." Cambridge Journal of Economics 17 (2): 131-57.

Diwan, Ishac, Philip Keefer, and Marc Schiffbauer. 2013. "The Effect of Cronyism on Private Sector Growth in Egypt." World Bank Group.

Freund, Caroline. 2016. Rich People Poor Countries: The Rise of Emerging-Market Tycoons and their Mega Firms. Peterson Institute for International Economics.

Hamilton, Bob, Sharif Mohammad, and John Whalley. 1984. "Rent Seeking and the North-South Terms of Trade.” Journal of Policy Modeling 6 (4): pp. 485-511.

Johnson, Chalmers. 1982. MITI and the Japanese Miracle: The Growth of Industrial Policy: 1925-1975. Stanford University Press.

Mazzucato, Mariana. 2013. "The Entrepreneurial State: Debunking Private vs. Public Sector Myths." London: Anthem Press.

Rodrik, Dani. 2014. “Green Industrial Policy.” Oxford Review of Economic Policy 30 (3): 469-91. 


\section{Back in Business: Industrial Policy for Emerging Economies in the New Globalization}

Today's emerging economies face a dual structural transformation challenge: (i) to move closer to the current world technology frontier (traditional catch-up), and (ii) to adjust to technological change in advanced economies and increasingly binding environmental and social constraints. They must do so subject to their available state capacity. The paradox of industrial policy is that it is most straightforward when state capacity is the most constrained. In this paper the authors suggest that emerging economies still should explore sector-based horizontal policies addressing market and state failures in individual industries in addition to broader policies to improve the investment climate and enhance state capacity.

\section{About the Asian Development Bank}

ADB's vision is an Asia and Pacific region free of poverty. Its mission is to help its developing member countries reduce poverty and improve the quality of life of their people. Despite the region's many successes, it remains home to a large share of the world's poor. ADB is committed to reducing poverty through inclusive economic growth, environmentally sustainable growth, and regional integration.

Based in Manila, ADB is owned by 67 members, including 48 from the region. Its main instruments for helping its developing member countries are policy dialogue, loans, equity investments, guarantees, grants, and technical assistance. 